Проведені експериментальні дослідження процесу сушіння високовологого насіння гарбуза у вібращійній сушариі, що обумовлено необхідністю вирішення проблеми швидкої та якісної його післязбиральної обробки з мінімальними витратами. Існуючі технологї та обладнання не забезпечують якісного виконання процесу сушіння у післязбиральний період або здійснюють його із значними витратами часу та ресурсів. Основним завданням дослідження є визначення раціональних параметрів процесу та обладнання для сушіння насіння гарбуза.

Внаслідок виконаних експериментальних досліджень кінетики вібрачійно-конвективного сушіння насіння гарбуза отримано раціональні параметри ведення прочесу: максимально допустима температура сушильного агента складає $t_{c a}=50{ }^{\circ} \mathrm{C}$, що відповідає максимально допустимій температурі нагрівання насіння $t_{\mu 2}=46,7^{\circ} \mathrm{C}$, за якої зерно зберігає кондичійні значення схожості та енергї̈ проростання. Значення максимально допустимої температури є на $0,3{ }^{\circ} \mathrm{C}$ меншою, ніж гранично допустима температура нагрівання для насіння гарбуза.

Результати дослідження інтенсифікуючої дії вібраційного впливу вказують на пряму залежність між частотою вібрацї̈ суиильної камери та тривалістю сушіння: чим більша частота, тим більща інтенсивність вібрачійно-конвективного сушіння, а також на скорочення тривалості сушіння із збільшенням амплітуди вібрачії.

Отримані результати підтверджують доцільність використання фільтрачійно-конвективної вібросушарки, яка забезпечує дотримання рачіональних параметрів сушіння, серед яких: температура і швидкість сушильного агенту, амплітуда, частота, заповнення робочої камери. Поєднання цих параметрів дозволяє здійснювати сушіння насінневого матеріалу з мінімальними витратами та збереженням високої його якості

Ключові слова: насіння гарбуза, віброкиплячий шар, швидкість сушіння, сушильний агент, вібраційно-конвективна сушарка, рачіональні параметри, конвективне сушіння

$$
\square
$$

\section{口-}

Received date 09.12.2019

Accepted date 07.02.2020

Published date 28.02.2020
UDC $633.1: 631.536 .24$
DOI: $10.15587 / 1729-4061.2020 .195203$

DOI: $10.15587 / 1729-4061.2020 .195203$

\section{DETERMINATION OF THE KINETICS OF THE PROCESS OF PUMPKIN SEEDS VIBRATIONAL CONVECTIVE DRYING}

G. Kale t n i k

Doctor of Economic Sciences, Professor Department of Administrative Management and

Alternative Energy Sources*

E-mail: vitontiras2017@gmail.com

0. Ts u rkan

$\mathrm{PhD}$, Associate Professor

Department of Technological Processes and Equipment of

Processing and Food Production*

E-mail: tsurkan_ov76@ukr.net

T. R i m a r

$\mathrm{PhD}$, Associate Professor

Department of Heat Engineering and

Thermal and Nuclear Power Plants

Lviv Polytechnic National University

S. Bandery str., 12, Lviv, Ukraine, 79013

E-mail: tan_ru@ukr.net

O. Stanis lavch u k

$\mathrm{PhD}$, Associate Professor

Department of Industrial Safety and Labor Protection

Lviv State University of Life Safety

Kleparivska str., 35, Lviv, Ukraine, 79007

E-mail: stok_oven@ukr.net

*Vinnitsa National Agrarian University

Soniachna str., 3, Vinnitsa, Ukraine, 21008

Copyright (C) 2020, G. Kaletnik, O. Tsurkan, T. Rimar, O. Stanislavchuk This is an open access article under the CC BY license (http://creativecommons.org/licenses/by/4.0)

\section{Literature review and problem statement}

In [2], the author investigates the process of drying pumpkin seeds in a stationary state, using the energy of the sun. The advantage of this method is the low energy costs, and the disadvantage is uneven heating of the layer during the processing cycle, which leads to considerable process duration.

In [3], the drying process in the moving layer is considered, where the suspended state of the seed material is ensured by blowing the drying agent at speeds of $2.39-2.87 \mathrm{~m} / \mathrm{s}$. This method does not guarantee uniform heating of the seed and causes additional energy consumption to provide the required speed of the drying agent.

In [4], the influence of the drying process on the quality properties of pumpkin oil was investigated. The 
influence of drying speed on the physiological maturity of melon seed was determined in [5]. These works do not give a clear understanding of the method and equipment of the process.

In [6], the results of studies of the material drying process in a vibrating dryer with an infrared emitter are presented. This method and equipment allows intensifying the drying process, but is not suitable for drying seed lots because there is a risk of local overheating of the seed surface, which immediately leads to the loss of germination ability and energy.

The same approach is observed in [7], but it is carried out using equipment different in design compared to the work [6].

In [8], the results of studies on drying granular materials with low humidity are highlighted, which greatly simplifies the mechanism for solving such a problem.

The researcher [9] described the results of studies on drying low-humidity seed material, which is also much simpler than drying high-humidity seed.

The work [10] presents the hydrodynamics of the filtration drying process of seeds with high initial humidity and the corresponding equipment for its implementation, which shows the method and equipment of drying. This approach intensifies the drying process on the example of high-moisture pumpkin seeds, while ensuring a gentle processing mode in order to preserve their quality. Continuation of the started researches in the work [10] is presented in the publication [11], which presents generalized results of studies of the $1^{\text {st }}$ period of filtration dehydration of freshly purified pumpkin seeds with vibration-pneumatic activation.

In [12], the results of studies of heat transfer processes during the drying of high-moisture pumpkin seeds in a vibratory fluidized bed are presented. It is shown that the drying process can be intensified using vibration equipment by blowing the treated material layer. But the issues of determining rational modes and parameters of the process and equipment, its energy efficiency remained unresolved. One way to overcome this problem may be to create pilot experimental samples of vibration drying equipment and to carry out appropriate experimental studies. This approach originates in $[10,11]$, where on the basis of experimental data, the basic analytical dependences characterizing the hydrodynamics and kinetics of filtration drying of freshly purified pumpkin seeds were obtained, in particular, the influence of the ratio of the vertical and horizontal components of vibration amplitude, and the feasibility of vibration activation during filtration drying is substantiated.

Known methods of intensifying the drying processes of thermolabile and especially seed materials do not provide a significant increase in efficiency while maintaining the conditions for preserving their sowing and nutritional qualities [8]. Therefore, there is a problem in further deepening of the scientific researches aimed at the development and substantiation of design-technological parameters and operating modes of vibration drying equipment for intensive energy-saving drying of these specific materials.

All this suggests that it is advisable to study the kinetics of the process of vibrational and convective drying of pumpkin seeds.

\section{The aim and objectives of the study}

The aim of this work is to determine the kinetics of vibration-convective drying of pumpkin seeds in the humidity range of $38-10 \%$. This will allow finding rational parameters of the process and equipment for drying seed lots of pumpkin seeds in order to preserve their conditioning properties.

To achieve this aim, the following objectives were defined:

- to substantiate the rational parameters of the process, in particular, the maximum permissible values of the temperature of the drying agent and heating of the pumpkin seed layer, as well as the feasibility of vibration activation, as a significant intensifying factor;

- to derive dependencies for calculating the duration and speed of drying of pumpkin seeds in the first period in the studied range of the process parameters.

\section{Materials and methods for determining the kinetics of the process of pumpkin seeds vibrational-convective drying}

The methods of theoretical and analytical mechanics, continuum mechanics, in particular visco-plasticity mechanics, mechanics of bulk discrete media, were used. Experimental studies used the methods of planning a factor experiment, methods of electrical measurements of non-electrical quantities.

Microsoft Excel, Grapher software packages were used to visualize the research results.

Determination of quality indicators of seeds was carried out in testing laboratories in accordance with NSU 4138-2002 and NSU 7160: 2010.

\section{Results of determining the kinetics of the process of pumpkin seeds vibrational-convective drying}

During the experimental study of the process of drying pumpkin seeds, it was found that the drying occurs in two stages. The first is vibrational and filtration drying of the material from the humidity of $52 \%$ to $38 \%$; the second is vibrational and convective drying from the humidity of $38 \%$ to $10 \%$. The hydrodynamics and kinetics of the first stage of drying were considered in [10, 11]. Experimental studies of the second stage of drying (vibrational and convective) were carried out using the pilot-industrial sample of filtration-convective vibrating dryer [12, 13], its schematic diagram is shown in Fig. 1.

The filtration-convective vibrating dryer consists of a drying chamber 1 mounted on elastic supports 2 . The working chamber, which is oscillated by means of a vibrator 3 , has a neck 4 above to remove the spent drying agent, and a perforated U-shaped bottom below. The supply system of the heated drying agent consists of a fan 6 and electric heating elements 7. Position 8 indicates the direction of movement of the drying agent, and position 9 - pumpkin seeds to be dried.

The filtration-convective vibrating dryer works as follows. The vibrator 3 drives the drying chamber 1 with pumpkin seeds 9 mounted on the elastic supports 2 . The dry- 
ing agent supplied by the fan 6 passes through the electric heating elements 7 , is heated to a predetermined temperature and, through the perforated U-shaped bottom 5 of the working chamber 1 , passes through the pumpkin seeds 9 in the direction 8 and is removed through the neck 4 .

Measurement of the coolant and seed layer temperature was carried out using thermocouples of ChC type and semiconductor integral thermometers of DS18B20 type. For research, pumpkin seeds of different ripeness, years of harvesting, degree of surface cleaning were used.

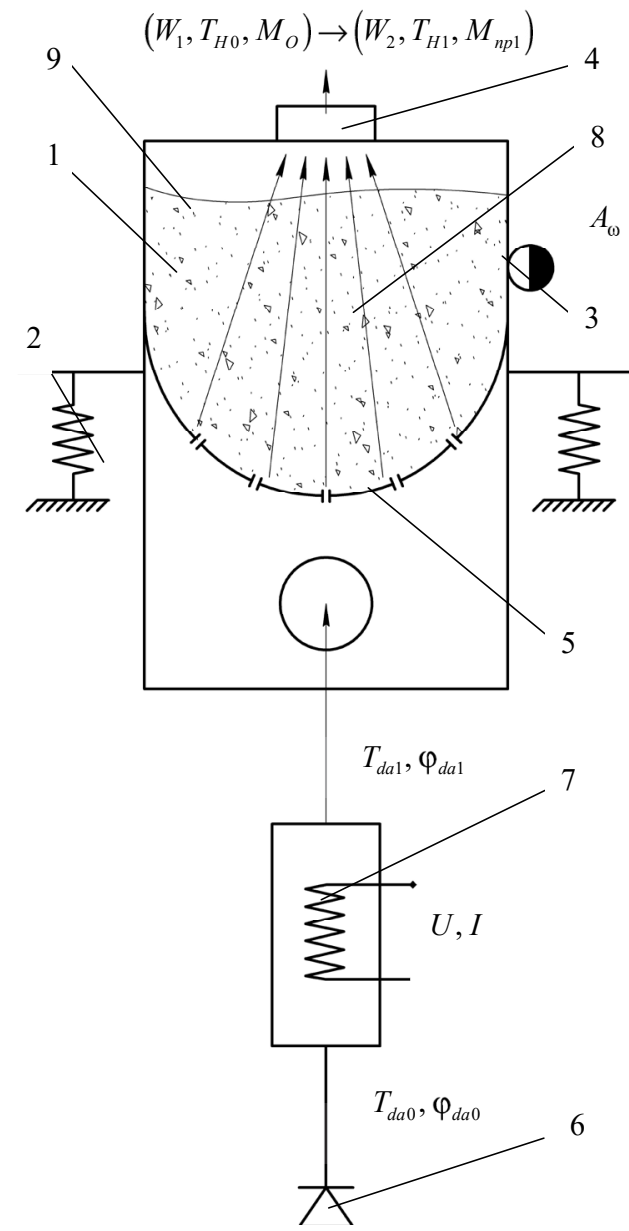

Fig. 1. Schematic diagram of the filtration-convective vibrating dryer: 1 - drying chamber; 2 - elastic supports; 3 - vibrator; 4 - neck; 5 - perforated U-shaped bottom;

6 - fan; 7 - electric heating elements; 8 - direction of

movement of the drying agent; 9 - pumpkin seeds

The initial values of pumpkin seed temperature (humidity $W=38 \%$ ) were taken considering the results of the previous stage studies - filtration drying [11].

The process of vibrational and convective drying of pumpkin seeds, based on the angle of inclination of the obtained dependence curves (Fig. 2,3), can be divided into two periods. In the first period of drying pumpkin seeds (in the humidity range of 38-17\%), intensive removal of moisture with a constant speed of drying due to evaporation from the surface of the dried material is observed. Therefore, in this humidity range, the kinetic curves are depicted by straight lines whose slope depends on the speed of the drying process. The second period (within the humidity range of $17-10 \%$ ) is characterized by a lower drying rate, which is shown on the kinetic curves (Fig. 2, 3) by curvilinear sections, the slope of which indicates the slowdown of the process.

The study of the kinetics of vibration-convective drying of pumpkin seeds was carried out under the following parameters: the filling factor of the drying chamber, the speed and temperature of the drying agent, the vibration amplitude of the drying chamber.

Investigation of the effect of the filling factor of the drying chamber $(1-0.25 ; 2-0.5 ; 3-0.75 ; 4-1)$ on drying kinetics was carried out at the drying agent temperature $t_{d a}=50{ }^{\circ} \mathrm{C}$, velocity $V_{d a}=0.6 \mathrm{~m} / \mathrm{s}$ and vibration acceleration $A \omega^{2}=138 \mathrm{~m} / \mathrm{s}^{2}$. As a result, it was found that if the drying chamber is $100 \%$ full, the total drying time increases by $1 / 3$ (from $4,000 \mathrm{~s}$ to $6,000 \mathrm{~s}$ ) compared to the drying time by filling the drying chamber by 0.25 . In the case of $100 \%$ complete filling of the drying chamber, the second drying period starts in 3,000 s and lasts 3,000 s, and when filled by $25 \%$ - in $2,100 \mathrm{~s}$ and lasts $1,900 \mathrm{~s}$. Therefore, there is a direct dependence - the increase in the duration of the first and second drying periods and the drying process as a whole on the filling factor of the drying chamber (Fig. 2).

Kinetic curves (Fig. 2-12) are constructed directly from the results of experimental studies of the process of vibration-convective drying of pumpkin seeds in a filtration-convective vibrating dryer (Fig. 1) with the following variables: the filling factor of the drying chamber, the speed and temperature of the drying agent, vibration amplitude of the drying chamber. The curves are constructed to study the regularity of the process itself depending on the variables. Kinetic curves are the initial stage for mathematical processing of the results of studying the kinetics of the drying process.

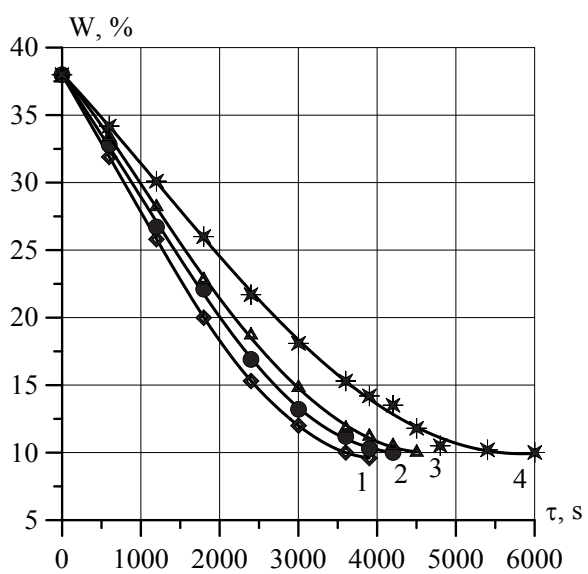

Fig. 2. Changes in the humidity of pumpkin seeds from the duration of vibration-convective drying at different filling factors of the drying chamber at $t_{d a}=50{ }^{\circ} \mathrm{C} ; V_{d a}=0.6 \mathrm{~m} / \mathrm{s}$; $A \omega^{2}=138 \mathrm{~m} / \mathrm{s}^{2}: 1-K_{f}=0.25 ; 2-\mathrm{K}_{\mathrm{f}}=0.5 ; 3-\mathrm{K}_{\mathrm{f}}=0.75$;

$$
4-K_{\mathrm{f}}=1.0
$$

Fig. 4, 5 contain the results of the study of the influence of the coolant velocity $(1-1 \mathrm{~m} / \mathrm{s} ; 2-0.8 \mathrm{~m} / \mathrm{s} ; 3-0.6 \mathrm{~m} / \mathrm{s}$; $4-0.4 \mathrm{~m} / \mathrm{s}$ ) on the kinetics of vibration-convective drying for the filling factor of the drying chamber $\mathrm{K}_{\mathrm{f}}=0.75$, vibration acceleration $A \omega^{2}=138 \mathrm{~m} / \mathrm{s}^{2}$ and coolant temperature $t_{d a}=50{ }^{\circ} \mathrm{C}$.

At the coolant velocity $V_{d a}=0.4 \mathrm{~m} / \mathrm{s}$, the first and the second drying periods last for 3,000 s (total drying time is $6,000 \mathrm{~s}$ ), and for $V_{d a}=1 \mathrm{~m} / \mathrm{s}$ - the second drying period begins in 2,000 seconds and lasts 1,600 s (total drying time 
is $3,600 \mathrm{~s})$. So, the coolant velocity also has a significant impact on the duration of the first and the second drying periods and the drying process of pumpkin seeds in general.

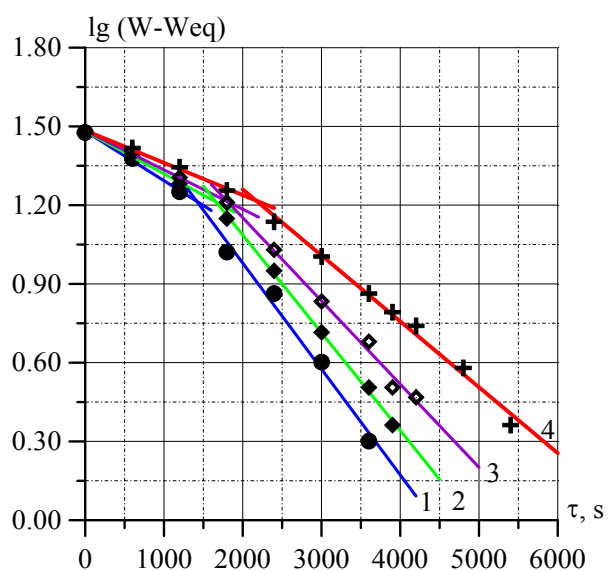

Fig. 3. Determination of the critical humidity of pumpkin seeds and the time of its achievement during vibrationconvective drying at different filling factors of the drying chamber at $t_{d a}=50{ }^{\circ} \mathrm{C} ; V_{d a}=0.6 \mathrm{~m} / \mathrm{s} ; A \omega^{2}=138 \mathrm{~s} / \mathrm{s}^{2}$ :

$1-K_{f}=0.25 ; 2-\mathrm{K}_{\mathrm{f}}=0.5 ; 3-\mathrm{K}_{\mathrm{f}}=0.75 ; 4-\mathrm{K}_{\mathrm{f}}=1.0$

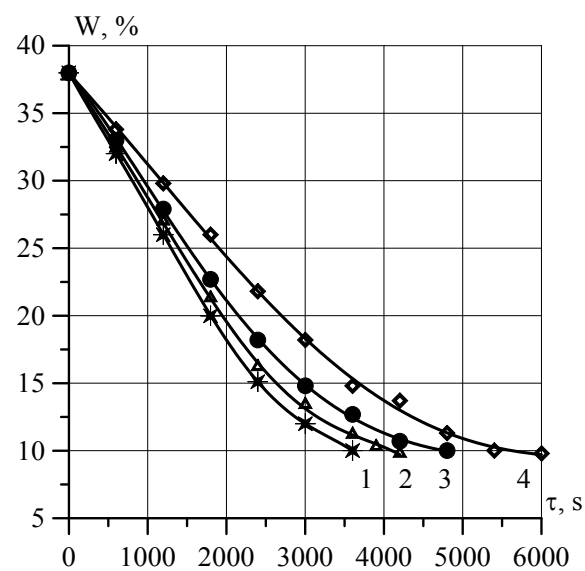

Fig. 4. Changes in the humidity of pumpkin seeds from the duration of vibration-convective drying at different speeds of the drying agent at $t_{d a}=50{ }^{\circ} \mathrm{C} ; K_{f}=0.75 ; A \omega^{2}=138 \mathrm{~m} / \mathrm{s}^{2}$ :

$1-V_{d a}=1 \mathrm{~m} / \mathrm{s} ; 2-V_{d a}=0.8 \mathrm{~m} / \mathrm{s} ; 3-V_{d a}=0.6 \mathrm{~m} / \mathrm{s}$; $4-V_{d a}=0.4 \mathrm{~m} / \mathrm{s}$

In order to justify the expediency of vibrational activation of the process, a study of the intensifying effect of the vibrational influence (vibration amplitude and frequency) was carried out.

The influence of the vibration amplitude of the drying chamber on the kinetics of drying was investigated by the filling factor of the drying chamber of 0.75 , coolant velocity of $0.6 \mathrm{~m} / \mathrm{s}$ and temperature of $60^{\circ} \mathrm{C}$ (Fig. 6).

The vibration amplitude was changed within $12-18 \mathrm{~mm}$. The results of the study (Fig. 6) indicate a reduction in the drying time with increasing vibration amplitude: for $A=12 \mathrm{~mm}$, the start time of the second drying period was recorded in 3,300 s, and the drying time as a whole was $7,200 \mathrm{~s}$; for $A=18 \mathrm{~mm}$, the second period occurs already in $2,200 \mathrm{~s}$ (which is 1.5 times faster) and lasts $900 \mathrm{~s}$, which is 4.3 times faster than for $A=2 \mathrm{~mm}$. The total drying time is reduced by almost 2.3 times and is $3,100 \mathrm{~s}$.

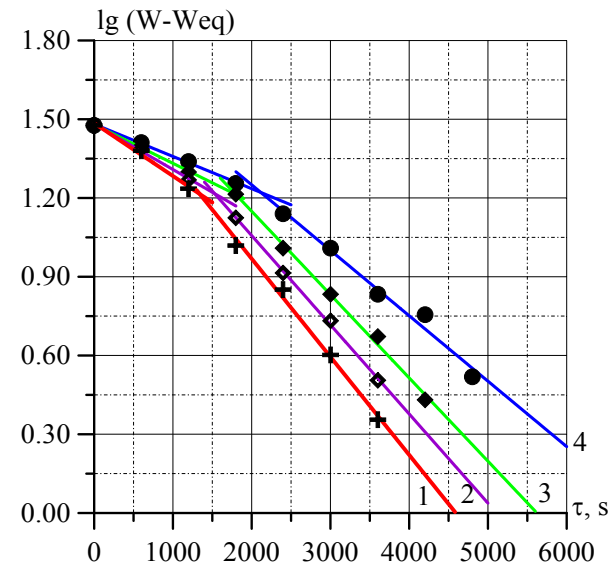

Fig. 5. Determination of the critical humidity of pumpkin seeds and the time of its achievement during vibrationconvective drying at different speeds of the drying agent at $t_{d a}=50^{\circ} \mathrm{C} ; K_{f}=0.75 ; A \omega^{2}=138 \mathrm{~m} / \mathrm{s}^{2}: 1-V_{d a}=1 \mathrm{~m} / \mathrm{s}$;

$2-V_{d a}=0.8 \mathrm{~m} / \mathrm{s} ; 3-V_{d a}=0.6 \mathrm{~m} / \mathrm{s} ; 4-V_{d a}=0.4 \mathrm{~m} / \mathrm{s}$

The results of the studies on the effect of vibration frequency $($ Fig. 8, 9) indicate a direct relationship between the vibration frequency of the drying chamber and drying time: the higher the frequency, the greater the intensity of vibration-convective drying. As can be seen from Fig. 8, for the vibration frequency $f=10 \mathrm{~Hz}$, the second period begins in 3,200 $\mathrm{s}$ and lasts $2,800 \mathrm{~s}$, and the total drying time is $6,000 \mathrm{~s}$. For the vibration frequency $f=25 \mathrm{~Hz}$, the second drying period begins in 2,000 seconds and lasts for 2,200 seconds, and the total drying time is 4,200 seconds, which is almost 1.5 times less than for $f=10 \mathrm{~Hz}$.

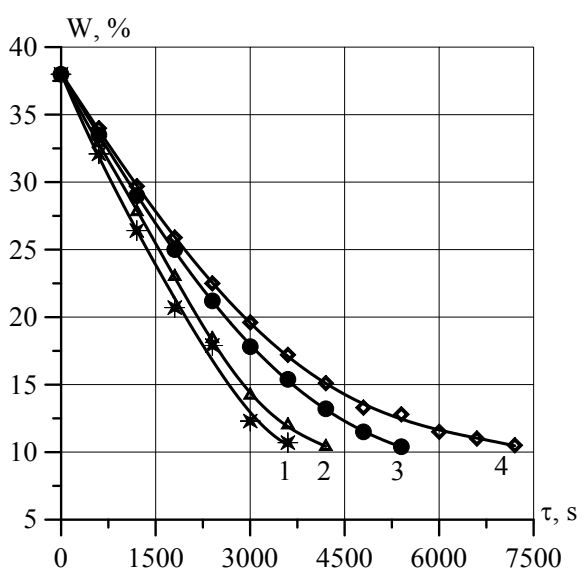

Fig. 6. Changes in the humidity of pumpkin seeds from the duration of vibration- convective drying at different speeds of the drying agent for $K_{f}=0.75 ; V_{d a}=0.6 \mathrm{~m} / \mathrm{s}$;

$A \omega^{2}=138 \mathrm{~m} / \mathrm{s}^{2} ; t_{d a}=50^{\circ} \mathrm{C}: 1-A=18 \mathrm{~mm} ; 2-A=16 \mathrm{~mm}$; $3-A=14 \mathrm{~mm} ; 4-A=12 \mathrm{~mm}$

The results of studying the influence of the coolant temperature in the range of $40-60{ }^{\circ} \mathrm{C}$ on the kinetics of vibration-convective drying of pumpkin seeds at a coolant velocity of $0.6 \mathrm{~m} / \mathrm{s}$, vibration acceleration $A \omega^{2}=138 \mathrm{~m} / \mathrm{s}^{2}$ and filling factor of the drying chamber of 0.75 are shown in Fig. 10, 11.

The obtained results indicate an increase in the process intensity, both in the first and second periods of drying with increasing temperature of the thermal agent. As can be seen from Fig. 10, at a temperature of $40{ }^{\circ} \mathrm{C}$, the second drying pe- 
riod begins in $3,600 \mathrm{~s}$ and lasts for almost $3,000 \mathrm{~s}$, the total drying time is $6,500 \mathrm{~s}$. At the coolant temperature of $60{ }^{\circ} \mathrm{C}$, the second period of drying occurs already in $1,800 \mathrm{~s}$ and lasts for $1,800 \mathrm{~s}$, and the total drying time is $3,600 \mathrm{~s}$, which is 1.8 times less than at $40{ }^{\circ} \mathrm{C}$. Consequently, the higher the coolant temperature, the more intense the drying process is.

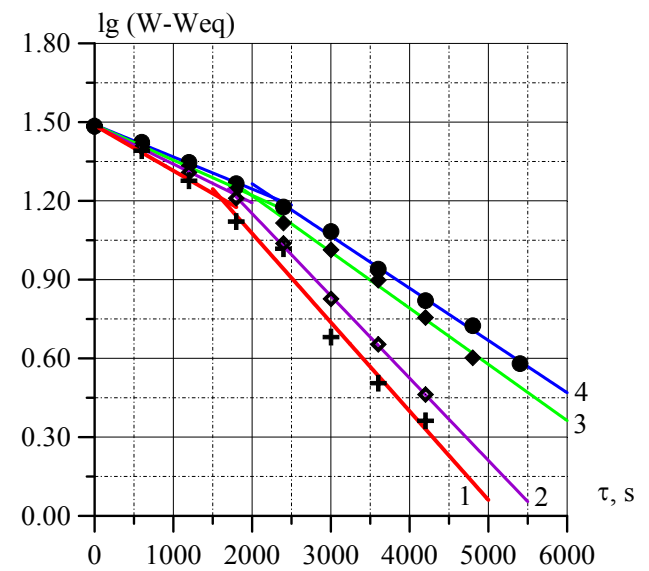

Fig. 7. Determination of the critical humidity of pumpkin seeds and the time of its achievement during vibrationconvective drying at different vibration amplitudes of the drying chamber for $K_{f}=0.75 ; V_{d a}=0.6 \mathrm{~m} / \mathrm{s}$; $A \omega^{2}=138 \mathrm{~m} / \mathrm{s}^{2} ; t_{d a}=50^{\circ} \mathrm{C}: 1-A=18 \mathrm{~mm} ; 2-A=16 \mathrm{~mm}$; $3-A=14 \mathrm{~mm} ; 4-A=12 \mathrm{~mm}$

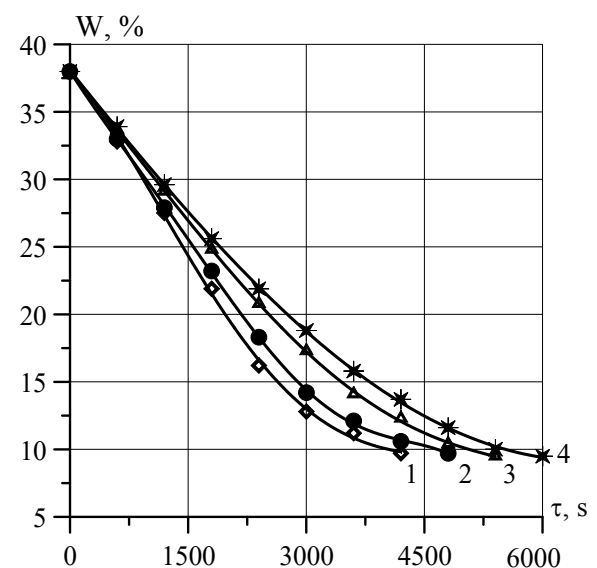

Fig. 8. Changes in the humidity of pumpkin seeds from the duration of vibration-convection drying at different vibration amplitudes of the drying chamber for: $K_{f}=0.75$;

$V_{d a}=0.6 \mathrm{~m} / \mathrm{s} ; t_{d a}=50^{\circ} \mathrm{C}: 1-f=25 \mathrm{~Hz} ; 2-f=20 \mathrm{~Hz}$;

$$
3-f=15 \mathrm{~Hz} ; 4-f=10 \mathrm{~Hz}
$$

However, the drying temperature of a product such as pumpkin seeds is limited to a certain level in order not only to reduce their humidity, but also to simultaneously preserve their germination ability and energy [14, 15]. In the reference literature $[16,17]$, it is determined that the maximum permissible heating temperature of pumpkin seeds is $t_{\mathrm{h} \text { max. permissible }}=47^{\circ} \mathrm{C}$ for the corresponding duration of the heating (drying) process. Detailed definitions of rational parameters of the drying process, taking into account the permissible values of the heating temperature of pumpkin seeds are highlighted in [18].

The average heating temperature of the seed surface was determined by the method of measuring «in a suddenly lowered layer» $[19,20]$, when the supply of coolant and vibration were temporarily stopped. The error of this measurement method does not exceed $0.5 \%$.

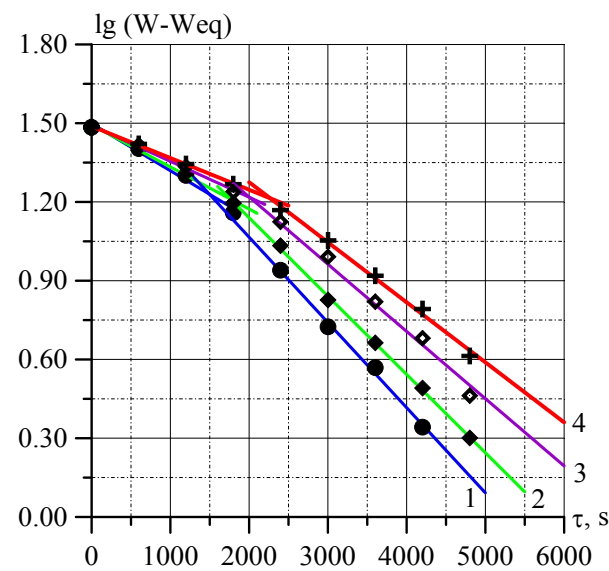

Fig. 9. Determination of the critical humidity of pumpkin seeds and the time of its achievement during vibrationconvective drying at different vibration amplitudes of the drying chamber for $K_{f}=0.75 ; V_{d a}=0.6 \mathrm{~m} / \mathrm{s} ; t_{d a}=50{ }^{\circ} \mathrm{C}$ : $1-f=25 \mathrm{~Hz} ; 2-f=20 \mathrm{~Hz} ; 3-f=15 \mathrm{~Hz} ; 4-f=10 \mathrm{~Hz}$

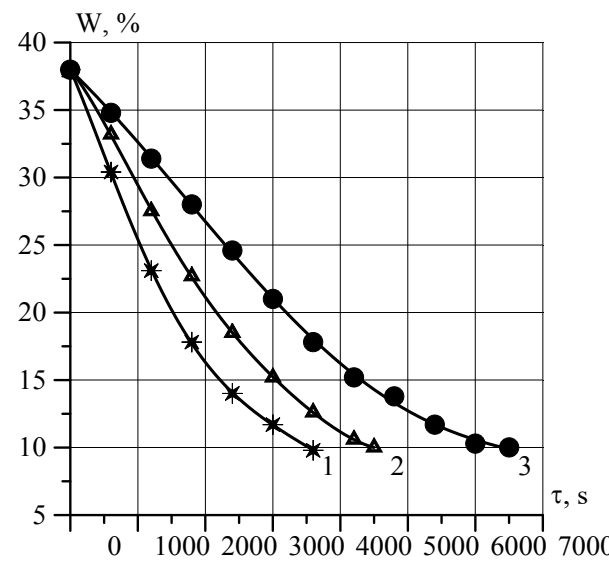

Fig. 10. Changes in the humidity of pumpkin seeds from the duration of vibration-convective drying at different temperatures of the drying agent for $K_{f}=0.75 ; V_{d a}=0.6 \mathrm{~m} / \mathrm{s}$; $A \omega^{2}=138 \mathrm{~m} / \mathrm{s}^{2}: 1-t_{d a}=60{ }^{\circ} \mathrm{C} ; 2-t_{d a}=50^{\circ} \mathrm{C} ; 3-t_{d a}=40^{\circ} \mathrm{C}$

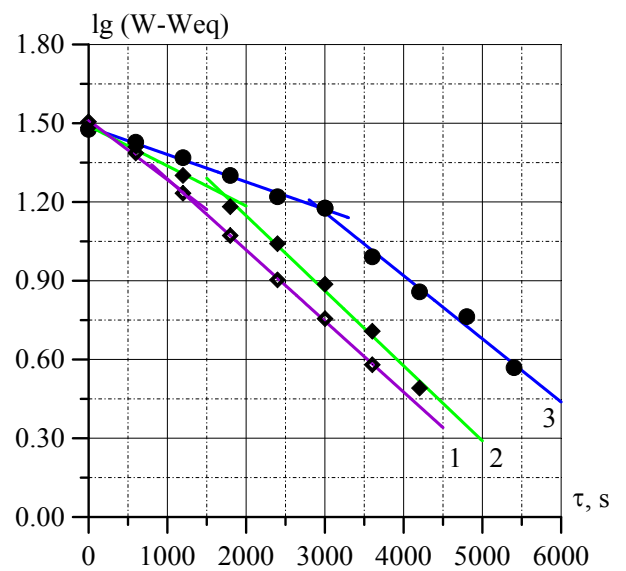

Fig. 11. Determination of the critical humidity of pumpkin seeds and the time of its achievement during vibrationconvection drying for different vibration frequencies of the drying chamber for $K_{f}=0.75 ; V_{d a}=0.6 \mathrm{~m} / \mathrm{s} ; A \omega^{2}=138 \mathrm{~m} / \mathrm{s}^{2}$ :

$$
1-t_{d a}=60{ }^{\circ} \mathrm{C} ; 2-t_{d a}=50{ }^{\circ} \mathrm{C} ; 3-t_{d a}=40{ }^{\circ} \mathrm{C}
$$


As a result of the research, it was found that during the drying of pumpkin seeds at a temperature of the thermal agent of $50^{\circ} \mathrm{C}$, the average heating temperature of the surface of the dried material is practically the same throughout the layer and does not exceed $t_{\mathrm{h} 2}=46.7^{\circ} \mathrm{C}$, that is, is within the permissible values.

Measurements of the nucleus (embryo) temperature of pumpkin seeds were not carried out, since they are suitable for conducting thorough research of the selection direction, in particular, the influence of temperature on the structural biochemical properties of seeds.

During the studies of the kinetics of vibration-convective drying, the dynamics of the surface heating temperature of pumpkin seeds was also determined (Fig. 12).

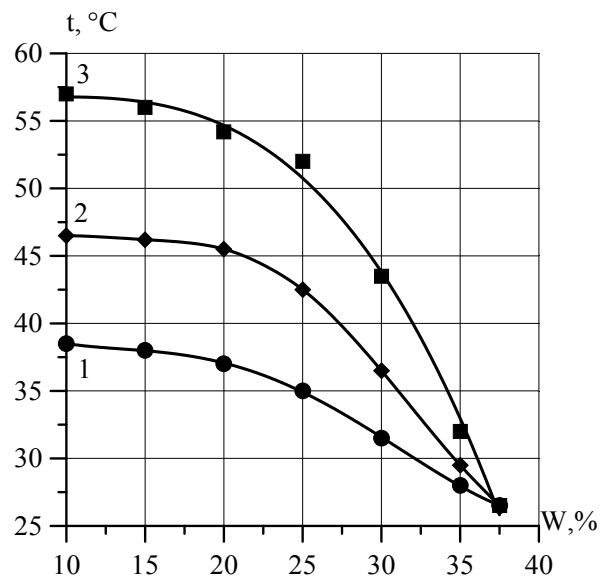

Fig. 12. Changes in the humidity of pumpkin seeds from the duration of vibration-convective drying at different temperatures of the drying agent for $K_{f}=0.75 ; V_{d a}=0.6 \mathrm{~m} / \mathrm{s}$; $A \omega^{2=} 138 \mathrm{~m} / \mathrm{s}^{2}: 1-40{ }^{\circ} \mathrm{C} ; 2-50{ }^{\circ} \mathrm{C} ; 3-60{ }^{\circ} \mathrm{C}$

To determine the values of the critical humidity of the seeds $W_{\text {cr }}$ at different temperatures and speeds of the drying agent, the filling factor of the drying chamber, as well as the drying time in the first period $\tau_{\mathrm{cr}}$, the method was used to construct kinetic curves in the $\lg \left(W-W_{\mathrm{p}}\right)=f(\tau)$ coordinates. On the basis of the results of experimental research, the critical humidity and the time of its achievement for different parameters of the drying agent and operating modes of the drying equipment were determined by the graph-analytical method. In order to find the dependence of the duration of vibration-convective drying of pumpkin seeds in the first period on the drying rate, we shall present the graphic dependence $N_{\exp }=f\left(\tau_{\mathrm{cr}}\right)$, shown in Fig. 13 .

The dependence of the critical drying time $\tau_{\mathrm{cr}}$ on the drying rate $N_{\exp }$ in the first period is described by the equation:

$$
\tau_{c r}=\frac{7.68}{N^{1.133}}
$$

The obtained dependence (1) is valid in the investigated range of the speeds of vibration-convective drying (Fig. 13), namely $0.0056 \% / \mathrm{s}<N<0.0125167 \% / \mathrm{s}$. The confidence factor of approximation $R^{2}$ is 0.942637 , which is quite acceptable and characterizes the smoothing as reliable. The obtained dependence coefficients are found to be statistically significant.

The drying rate in the first period $N$ will depend on the operating parameters of the drying equipment and can be represented in general by the equation [8]:
$N=A \cdot t_{d a}^{m} \cdot K_{f}^{n} \cdot V_{d a}^{k}$.

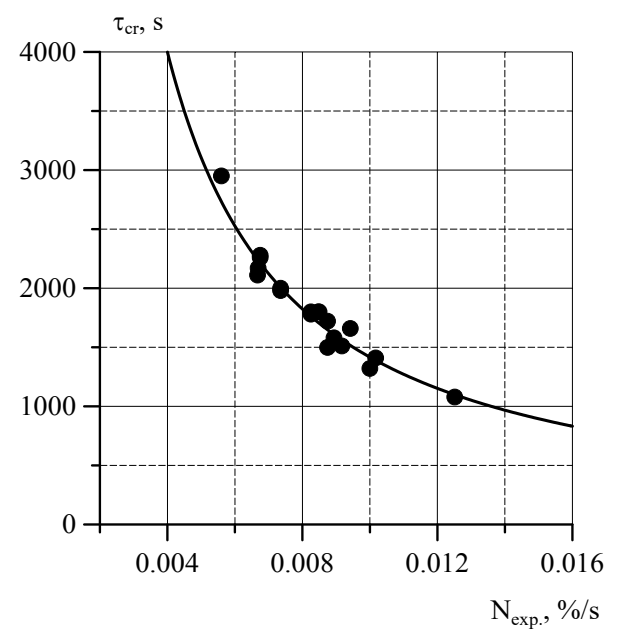

Fig. 13. Dependence of the speed of vibration- convective drying $N$ of pumpkin seeds on the critical drying time $\tau_{\mathrm{cr}}$

According to the calculations, the unknown coefficients of the drying process are found, then the drying rate in the first period of vibration-convective drying of pumpkin seeds can be determined by the equation:

$$
N_{p}=1,016 \cdot 10^{-5} \cdot t_{d a}^{1.74} \cdot K_{f}^{-0.33} \cdot V_{d a}^{0.366} .
$$

The calculated empirical dependence (3) is valid in the studied range of:

- coolant temperature $40{ }^{\circ} \mathrm{C}<t_{d a}<60{ }^{\circ} \mathrm{C}$;

- coolant velocity $0.40 \mathrm{~m} / \mathrm{s}<V_{d a}<1 \mathrm{~m} / \mathrm{s}$;

- drying chamber filling factor $0.25<\mathrm{K}_{\mathrm{f}}<1$.

The confidence factor of linear approximation $R^{2}$ is 0.954705 , which is quite acceptable. The obtained dependence coefficients are found to be statistically significant.

From the analysis of equation (3), it can be seen that with the growth of coolant temperature and velocity, the drying rate in the first period increases, and with the increase of the filling factor of the drying drum (the height of the pumpkin seed layer), respectively, decreases. This is confirmed by numerical experimental studies [8]. Comparison of the calculated and experimental values of the drying rate of pumpkin seeds in the first period is satisfactory, and the relative error does not exceed $8 \%$, which is a permissible value.

\section{Discussion of results of determining the kinetics of} the process of pumpkin seeds vibration-convective drying

The graphs (Fig. 2-12) obtained by conducting experimental studies to determine the dependencies of the study of the kinetics of the process of vibrational and convective drying of pumpkin seeds make it possible to summarize them for determining rational parameters:

$-K_{f}=0.75$, typical for most vibration machines;

$-A=18 \mathrm{~mm}$, corresponds to the largest pumpkin seed size;

$-V_{d a}=0.6 \mathrm{~m} / \mathrm{s}$, sufficient for the drying agent to access the surface of each seed without affecting its trajectory;

$-t_{d a}=50{ }^{\circ} \mathrm{C}$, provides a thermal effect on pumpkin seeds without exceeding the maximum allowable heating temperature. 
Smaller values of these parameters would not intensify the drying process and larger ones would require additional energy.

The above rational parameters make it possible to obtain the dependencies (1)-(3) for calculating the duration and speed of drying pumpkin seeds.

The conducted researches prove the feasibility of using mechanical vibrations in the process of drying high-moisture pumpkin seeds, as this will provide intensive and energysaving modes of processing with a simultaneous sparing effect on the seed material.

The advantages are determination, substantiation and coordination of rational technological and operating parameters of the process and equipment of vibrational and convective of pumpkin seeds.

The disadvantages are that the work was limited to studies of one crop, which requires verification of the results obtained when used for other crops.

The results obtained are practically significant for drying sowing lots of pumpkin seeds in agricultural enterprises, as they guarantee high quality of the seed material, which has been tested in a certified laboratory according to [14]: germination ability - at least $95 \%$; germination energy not less than $90 \%$.

The presented studies are the final stage of the complex of studies of vibrational and mechanical intensification of pumpkin seed drying in the post-harvest period.
Thus, the performed work gives grounds to claim that the scientific hypothesis of drying high-moisture pumpkin seeds in two stages using vibrating equipment by providing the required mode of vibration movement of the processed material in the working chamber with gentle processing modes is correctly formulated and theoretically and experimentally justified.

\section{Conclusions}

1. Rational parameters of the process of vibrational-convective drying of pumpkin seeds are determined, in particular, the maximum permissible temperature of the drying agent is $t_{d a}=50{ }^{\circ} \mathrm{C}$, which corresponds to the maximum permissible heating temperature of seeds $t_{\mathrm{h} 2}=46.7^{\circ} \mathrm{C}$, at which the grain retains the conditioning values of germination ability and germination, coolant velocity is $0.6 \mathrm{~m} / \mathrm{s}$, vibration acceleration $A \omega^{2}=138 \mathrm{~m} / \mathrm{s}^{2}$, filling factor of the drying chamber $\mathrm{K}_{3}=0.75$, vibration amplitude of the drying chamber $A=18 \mathrm{~mm}$, and drying time is $105 \mathrm{~min}$.

2. The dependence was determined for calculating the duration and speed of pumpkin seeds drying, taking into account the operating parameters of the vibrating dryer in a certain range: coolant temperature is $40{ }^{\circ} \mathrm{C}<t_{d a}<60{ }^{\circ} \mathrm{C}$; coolant velocity is $0.40 \mathrm{~m} / \mathrm{s}<V_{d a}<1 \mathrm{~m} / \mathrm{s}$; drying chamber filling factor is $0.25<K_{f}<1$.

\section{References}

1. Poperechnyi, A. M., Korniychuk, V. H., Zhdanov, I. V. (2011). Matematychne modeliuvannia protsesu sushinnia kharchovoi syrovyny v susharkakh aerovibrokypliachoho sharu. Visnyk Donetskoho natsionalnoho universytetu ekonomiky i torhivli imeni Mykhaila Tuhan-Baranovskoho, 1, 67-73.

2. Akyol, E., Susantez, Ç., Kahveci, K. et. al. (2015). Drying simulation of pumpkin seed. Proceedings of the World Congress on Mechanical, Chemical, and Material Engineering, 320, 320-1-320-5.

3. Mujaffar, S., Ramsumair, S. (2019). Fluidized Bed Drying of Pumpkin (Cucurbita sp.) Seeds. Foods, 8 (5), 147. doi: https:// doi.org/10.3390/foods8050147

4. Ogrodowska, D., Tańska, M., Brandt, W. (2017). The Influence of Drying Process Conditions on the Physical Properties, Bioactive Compounds and Stability of Encapsulated Pumpkin Seed Oil. Food and Bioprocess Technology, 10 (7), 1265-1280. doi: https:// doi.org/10.1007/s11947-017-1898-z

5. Silva, H. W. da, Oliveira, J. A., Monfort, L. H. F., Santos, J. M. dos, Trancoso, A. C. R., Carvalho, M. V. de. (2017). Physiological maturity and drying speed in the quality of zucchini ( Cucurbita pepo L.) seeds. Journal of Seed Science, 39 (2), 142-149. doi: https:// doi.org/10.1590/2317-1545v39n2171033

6. Bandura, V., Kalinichenko, R., Kotov, B., Spirin, A. (2018). Theoretical rationale and identification of heat and mass transfer processes in vibration dryers with IR-energy supply. Eastern-European Journal of Enterprise Technologies, 4 (8 (94)), 50-58. doi: https:// doi.org/10.15587/1729-4061.2018.139314

7. Poperechnyi, A. M., Myronova, N. O. (2007). Kinetyka protsesu sushinnia plodovykh kistochok u vibrokypliachomu shari pry infrachervonomu nahrivanni. Visnyk Kharkivskoho natsionalnoho tekhnichnoho universytetu silskoho hospodarstva im. P. Vasylenka «Suchasni napriamky tekhnolohiyi ta mekhanizatsiyi protsesiv pererobnykh ta kharchovykh vyrobnytstv», 58, 122-129.

8. Kalinovskaya, O. P., Labay, V. I., Sushko, I. I. (1973). O novom klasse vibratsionnyh konvektivnyh sushilok. Vibratsionnaya tehnika v mashinostroenii i priborostroenii. Lviv, 212-214.

9. Shcherbakov, S. Yu. (2005). Issledovanie sushki semyan svekly v vibrokipyashchem sloe. Sbornik nauchnyh trudov posvyashchennyh 55-letiyu inzhenernogo fakul'teta. Ryazan', 145-147.

10. Tsurkan, O. V., Herasymov, O. O., Rymar, T. I. et. al. (2014). Hidrodynamika protsesu filtratsiynoho znevodnennia svizheochyshchenoho nasinnia harbuza z vibratsiynoiu aktyvatsieiu. Vibratsii v tekhnitsi ta tekhnolohiyakh, 2 (74), 138-144.

11. Tsurkan, O. V., Herasymov, O. O., Polievoda, Yu. A. et. al. (2015). Uzahalnennia kinetyky 1-ho periodu filtratsiynoho znevodnennia svizhoochyshchenoho nasinnia harbuza z vibratsiyno-pnevmatychnoiu aktyvatsieiu. Naukovi pratsi Natsionalnoho universytetu kharchovykh tekhnolohiy, 21 (2), 151-159.

12. Tsurkan, O., Gerasimov, O., Polyevoda, Y. et. al. (2017). Kinetic features of vibrating and filtration dewatering of fresh-peeled pumpkin seeds. INMATEH - Agricultural Engineering, 52 (2), 69-76.

13. Tcurkan, O. V., Kotc, I. V., Herasymov, O. O., Gorbatuk, V. A. (2012). Pat. No. 79839 UA. Method for drying seed. No. a201215176; declareted: 29.12.2012; published: 13.05.2013, Bul. No. 9 . 
14. DSTU 7160:2010. Nasinnia ovochevykh, bashtannykh, kormovykh i priano-aromatychnykh kultur. Sortovi ta posivni yakosti. Tekhnichni umovy (2010). Kyiv, 16.

15. Golubkovich, A. V., Chizhikov, A. G. (1991). Sushka vysokovlazhnyh semyan i zerna. Moscow, 235.

16. Konenkov, P. F., Seytbaev, K. Zh. (1990). Temperaturnye rezhimy sushki semyan bahchevyh kul'tur. Selektsiya i semenovodstvo, 3, 47-49.

17. Ludilov, V. A. (2005). Semenovedenie ovoshchnyh i bahchevyh kul'tur. Moscow, 392.

18. Fesenko, A. V. (2004). Optimizatsiya tehnologicheskih i konstruktivnyh parametrov zernosushilki v psevdoszhizhennom sloe. Zbirnyk naukovykh prats Luhanskoho natsionalnoho ahrarnoho universytetu, 42 (54), 150-153.

19. Dobritskiy, A. A. (2006). Issledovanie protsessa sushki semyan bahchevyh kul'tur v psevdoozhizhennom sloe. Zbirnyk naukovykh prats Luhanskoho natsionalnoho ahrarnoho universytetu, 64/87, 122-126.

20. Tsurkan, O. V., Liubin, M. V., Herasymov, O. O. et. al. (2012). Planuvannia bahatofaktornoho eksperymentu dlia doslidzhennia protsesu sushinnia u vibratsiyniy mashyni. Zbirnyk naukovykh prats (Haluzeve mashynobuduvannia, budivnytstvo), 2 (2 (32)), 196-203.

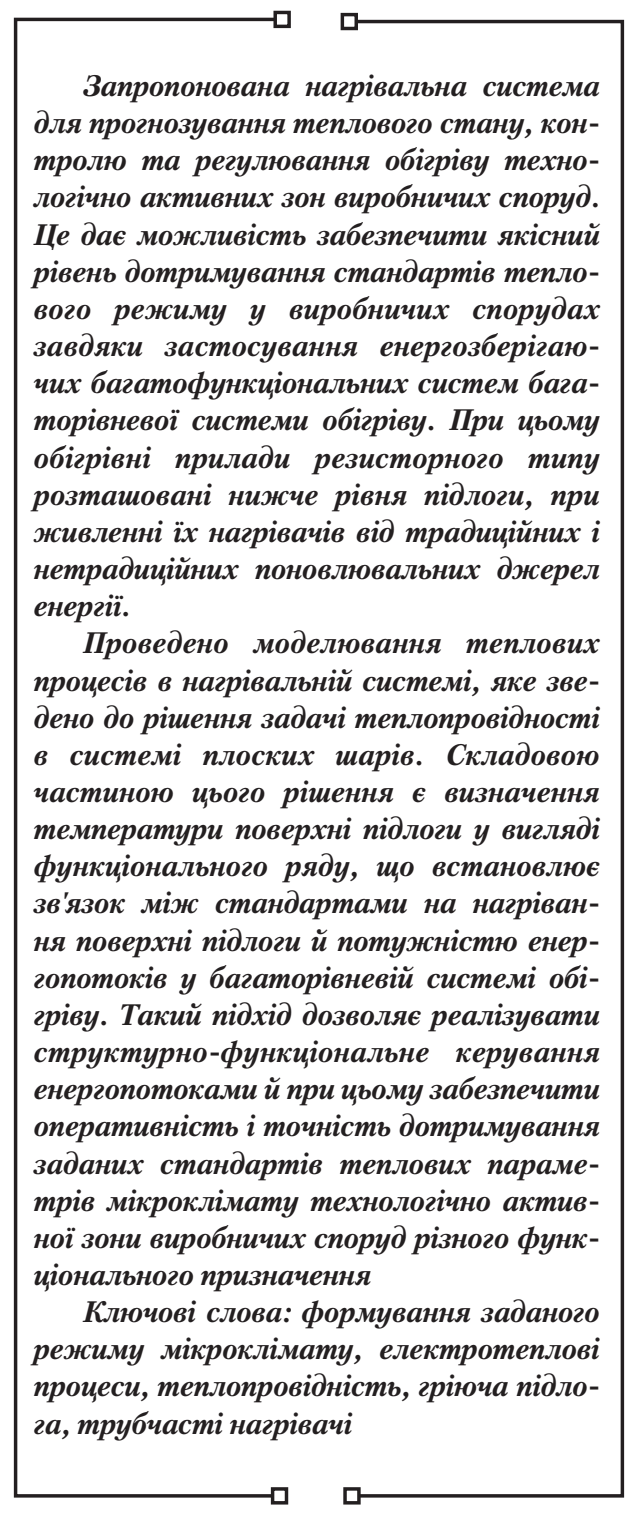

Received date 10.12.2019

Accepted date 14.02.2020

Published date 28.02.2020

UDC 631.2:631.171:65.011.56

DOI: $10.15587 / 1729-4061.2020 .196763$

\title{
CREATING A MICROCLIMATIC THERMAL MODE BY THE MULTILEVEL SYSTEM FOR HEATING INDUSTRIAL STRUCTURES
}

\author{
N. Rom a n che n ko \\ $\mathrm{PhD}$, Professor \\ Department of Integrated Electrotechnologies and Processes \\ Educational and Scientific Institute of Power Engineering and \\ Computer Technologies** \\ E-mail: betso@ukr.net \\ V. Rom a n che n ko \\ PhD, Associate Professor, Deputy Director \\ Educational Scientific Institute of Technical Service** \\ E-mail: betso@ukr.net \\ N. K y nde n ko \\ Doctor of Technical Sciences, Professor, Head of Department* \\ E-mail: n.p.kundenko@ukr.net \\ Y u. S a n i n \\ Postgraduate Student \\ *Department of Integrated Electrotechnology and Processes \\ Educational-Scientific Institute of Power Engineering and \\ Computer Technologies** \\ E-mail: betso@ukr.net \\ **Kharkiv National Technical University of \\ Agriculture named after Petr Vasilenko \\ Alchevskykh str., 44, Kharkiv, Ukraine, 61002 \\ Copyright (C) 2020, N. Romanchenko, V. Romanchenko, N. Kyndenko, Yu. Sanin \\ This is an open access article under the CC BY license \\ (http://creativecommons.org/licenses/by/4.0)
}

\section{Introduction}

Increasing the productivity of livestock bio-objects is an important and quite complex economic problem. Its complete or partial solution requires systematic fundamental re- search and applied developments aimed at the construction of the theoretical foundations of automated environmentally safe and resource-saving electro-technical complexes. These complexes ensure the thermal mode of the microclimate of production premises and structures and determine optimal 